\title{
DEVELOPING PHYSICS MONOPOLY GAME LEARNING MEDIA FOR LIGHT AND OPTICAL DEVICES
}

\author{
Aprilia Mayang Sari*1, Indra Gunawan ${ }^{2}$ \\ ${ }_{1,2}$ Physics Education Department, Tarbiyah and Teacher Training Faculty, UIN Raden Intan Lampung, Indonesia \\ *Correspondence address: Apriliamayangsari@yahoo.com
}

Accepted: October $30^{\text {th }}, 2017$. Approved: March $10^{\text {th }}, 2018$. Published: April $28^{\text {th }}, 2018$

\begin{abstract}
This study aims to determine the specific needs, feasibility, and responses of teachers and students toward the developed physics learning media of monopoly game on the light and optical devices material. The research procedure was based on the 4-D model. The subjects of this study were the students of State Junior High School 2 Gadingrejo. Data was collected through questionnaire. The data collected were analyzed using descriptive statistics. The results of this study were; 1) to know the specific needs in the form of filters by researchers to eliminate, replace, or modify the various components of the game into educational elements and the need for materials such as paper art paper and linen suitable for printing monopoly game designs; 2) to know the media feasibility through media and material expert's judgement. The average scores gained through the expert judgment were 4.45 and 4.24 respectively that fall into a very high category; 3) Teacher and student responses fall into the very high category with the mean score of 4.24 from teachers, 4.53 from small group testing and 4.59 from field-testing.
\end{abstract}

(C) 2018 Physics Education, UIN Raden Intan, Lampung, Indonesia

Keywords: learning media, light and optical devices, monopoly game

\section{INTRODUCTION}

Education is very important for every individual to survive in these difficult times. Education could produce human beings that benefit themselves, others, society, even for the nation. An educated or knowledgeable man is different from an uneducated or illiterate man. Allah has even described His appreciation of those who are knowledgeable and educated on QS.alMujadalah verse 11 as follows.

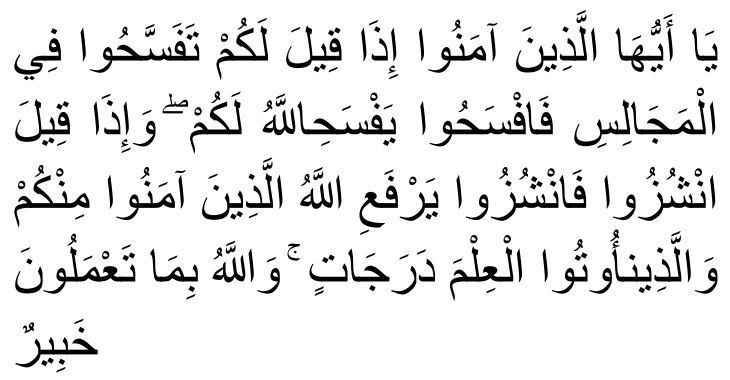

Meaning: O you who have believed, when you are told, "Space yourselves" in assemblies, then make space; Allah will make space for you. And when you are told, "Arise," then arise; Allah will raise those who have believed among you and those who were given knowledge, by degrees. And Allah is Acquainted with what you do.

The Qur'an verse illustrates the importance of education for human life. Given the condition of the quality of education in Indonesia is still relatively low as indicated data from the United Nations Development Program (UNDP) on the Human Development Index rating which includes the development of education. It shows a downgrade up to recent years, and based on the data from Research And Development Agency of the Ministry of National Education it is known that from 146,052 elementary schools, there are only 8 elementary schools, from 20,918 junior high schools there are only 8 junior high schools, and from 8,036 Senior High School there are only 7 Senior High Schools, which received world recognition (Relisa, 2016). So, the government continues to 
make efforts to improve the quality of education in Indonesia.

One of the government's efforts in improving the quality of education in Indonesia is to set the National Education Standards (SNP), including the standard process and standard facilities and infrastructure. In the standard process, the government has determined that learning processes in educational units are organized interactively, inspiratively, fun, challenging, and able to motivate students to participate actively, and provide sufficient space for initiative, creativity, and independence according to the talents, interests, and development of the students' physical and psychological (Peraturan Pemerintah Republik Indonesia, 2005).

Whereas in the standard of facilities and infrastructure, the government stipulates that every educational unit must have facilities that include furniture, educational equipment, educational media, books and other sources of learning, consumables items, and other equipment necessary to support a regular and continuous learning process (Peraturan Pemerintah Republik Indonesia, 2005). Based on the above government regulations, teachers are basically one of the elements that are directed to be able to create a learning condition in accordance with these standards.

Teachers in the learning process are not only required to deliver the learning materials as a whole but also required to be able to present the learning process in accordance with the interest of the students so as to grow and increase the motivation of students to participate actively and following the learning process. This is in accordance with research conducted by Rahma and Dian that educators have an obligation to meet the needs of learners (Manrulu \& Sari, 2015).
Physics is one of science that studies natural physiological phenomena (Diani, 2015). The non-living natural phenomena or matter in the domain of space and time are learned in physics. Many theories of physics are denoted in mathematical notation, and the mathematics used is usually more complicated than the mathematics used in other fields of science.

This fact often leads to the assumption by the students that physics is a difficult subject to understand and ultimately has implications to lower the student physics interest, therefore a physics teacher has the task of providing learning tools and creating interactive, inspirational, , challenging, and able to motivate the students to participate actively, and providing sufficient space for initiative, creativity, and independence according to the talents, interests, and physical and psychological development of learners (Simbolon \& Sahyar, 2015).

The general conditions in the field suggest that physics teaching in schools is more often performed in the classroom and using lecturing methods. Students only listen to explanations from the teacher without getting involved in the learning process. This is what causes students to become passive and less able to interact with each other (Komikesari, 2016). In physics, there are abstract and complex concepts, so it will be difficult for learners to understand the concepts if the learning process is still done using traditional learning methods (Magdin \& Turcanini, 2016; A Saregar \& Sunarno, 2013). Selection of appropriate learning methods and in accordance with the characteristics of learners can achieve learning objectives (Antomi Saregar, Latifah, \& Sari, 2016; Yusuf \& Amin, 2016). The use of appropriate learning media can help students in understanding the concepts taught, as proposed by Peoples, the use of relevant media will 
make the learning process effective and efficient. All the knowledge we get is $75 \%$ from seeing, $13 \%$ from listening, and $12 \%$ from tasting, kissing and touching (Hatika, 2016).

In addition to these advantages, in learning, there are still many teachers who are not utilizing the development of learning media today.

After conducting a preliminary study at State Junior High School 2 Gadingrejo, the researchers also found similar conditions with the problems described above. It is shown through the facts gathered on the field that the learning process undertaken by the teacher is still not utilizing the development of learning media. The result could be seen from the questionnaire distributed to the students, that the use of varied learning media scored $40 \%$. Another result of the questionnaire is that the students needed to use learning media in physics lesson with a percentage of $72.5 \%$. Students enjoyed the learning using power point, simulation, interactive video, and other interesting media as much as $72.5 \%$. Students felt that interesting and fun learning media can assist them in studying physics with a percentage of $87.5 \%$.

Based on the various problems above, it is necessary to develop a new learning media that has the concept of learning while playing; one example is the physics game monopoly. physics monopoly Game was developed because it has several advantages over other learning media, namely (1) the game is fun and entertaining, (2) the game allows an active participation of the students to learn, (3) the game can provide direct feedback, (4) the game allows the application of concepts or roles into the actual situation and role in the community, (5) the game is flexible, (6) the game can be easily created and reproduced (Sadiman, 2012). Thus, researchers feel the need to conduct research entitled Developing Physics Monopoly Game Learning Media for Light and Optical Devices.

\section{METHOD}

The stages of development were based on the 4D model developed by Thiagarajan. The final product is in the form of physics monopoly game on the subject of light and optical instrument.

The development was done through research and development method. The development model used was the 4D model that includes 4 stages, namely: 1). Definition stage (defining), 2). Planning (designing), 3). Development stage, and 4). Dissemination phase (Wardoyo \& Ma'arif, 2015).

This study was limited up to the development stage the time available and limited funds. The subjects of the study were eight grade students of State Junior High School 2 Gadingrejo. The research data was collected by using expert validation questionnaire, teacher response questionnaire, and student response questionnaire and then later analyzed using descriptive statistics.

The formula to count the averages:

$$
\bar{x}=\frac{\Sigma x}{n}
$$

exp:

$\bar{x} \quad=$ Average score

$\Sigma x \quad=$ score gained

$n \quad=$ number of subjects

The interpretation of the media, content expert validation score, as well as the physics teacher and the students' score, can be seen in the following table:

Table 1. Scoring system

\begin{tabular}{ll}
\hline Category & Score \\
\hline Very High & 5 \\
High & 4 \\
Moderate & 3 \\
Poor & 2 \\
Very poor & 1 \\
\hline
\end{tabular}


The average score gained in the research is interpreted I the following table 2 (Sartikaningrum, 2013).

Table 2 the interval of the media and content experts as well as the teacher and the students' score

\begin{tabular}{cll}
\hline No. & Range & Criteria \\
\hline 1. & $X>4,01$ & Very High \\
2. & $3,34<\mathrm{X} \leq 4,01$ & High \\
3. & $2,26<\mathrm{X} \leq 3,34$ & Moderate \\
4. & $1,99<\mathrm{X} \leq 2,26$ & Poor \\
5. & $\mathrm{X} \leq 1,99$ & Very poor \\
\hline
\end{tabular}

Table 2 is used as the basis of the average score from the experts, teacher, and the students toward the developed learning media. The feasibility of the product will fall in the Very High category if $X>4,01$; Good if $3,34<X \leq$ 4,01; Moderate if 402,26 $<\mathrm{X} \leq 3,34$; Poor if $1,99<X \leq 2,26$ and very Poor if $\mathrm{X} \leq 1,99$.

\section{RESULT AND DISCUSSION}

The first result of this research is intended to investigate the specific needs of the development learning media, such as the need for filters by researchers to eliminate, replace, or modify the various components that allow the appearance of negative impression in learners to be components related to education, it needs materials such as art-paper and linen that have good quality to print the game design. These needs are identified after performing several stages of defining, designing, and developing.

The second result was intended to investigate the feasibility of instructional media through expert validation as well as through the teacher and students' response to the developed learning media, each is described as follows.

The validation was done by six experts consisting of 3 experts of media and 3 experts of material. Validation of the media experts was done by filling out an assessment questionnaire consisting of two aspects: the aspect of media engineering and the visual communication aspect. While the validation by the material experts was done by filling out the assessment questionnaire that consists of learning aspects. After validation by the experts, the next step was the design revision. The result of the revision was then used as a material to request an assessment to the physics teacher and to conduct the product field-testing on the seventh-grade students

\section{a. Media Experts Validation}

The result of media engineering and media communication toward the developed product is presented in the following table.

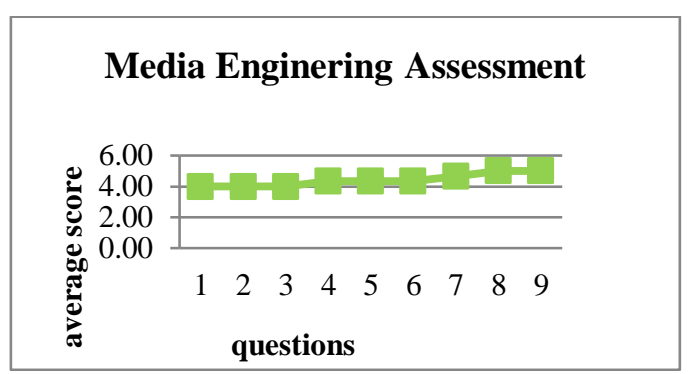

Figure 1. Average Score of the media engineering aspect

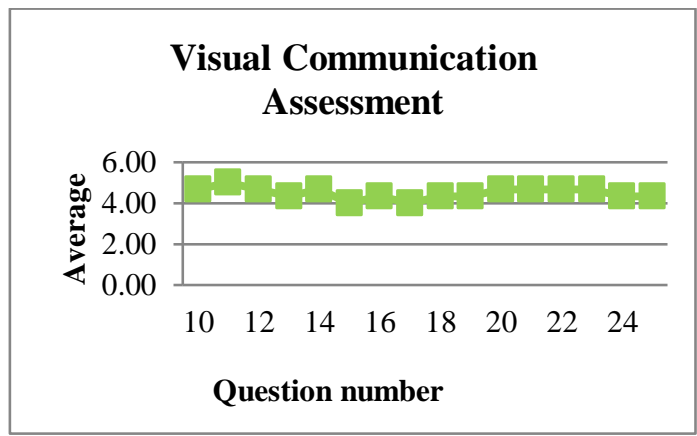

Figure 2. The average score of the visual communication aspects

Based on the calculations, the average score of 4.41 that falls into the very high category on the aspects of media engineering was obtained through nine questions, and the score of 4.48 which fall into the very high criteria for visual communication aspects was obtained using 16 questions. The average 
score obtained for all aspects was 4.45 so that the feasibility of the developed learning media is in the very high category

\section{b. Material Expert Validation}

The result of material expert validation on the developed product is presented in graphical form in Figure 3:

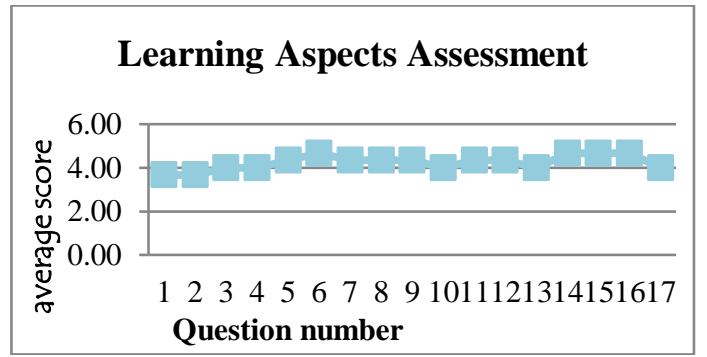

Figure 3. The average score of learning aspects by the material experts

Based on the calculation, the result of the validation of the experts obtained the average score of 4.24 which is in the very high criteria for the learning aspect which includes 17 questions, so that the feasibility of learning media of physics monopoly game based on the assessment by the material expert is in the very high criteria.

\section{B. Physics Teacher Response}

The response of the physics teacher toward the physics monopoly game was given through 3 aspects of assessment consisted of media engineering, visual communication aspect, and learning aspect. These results are generally presented in graphical form in Figure 4:

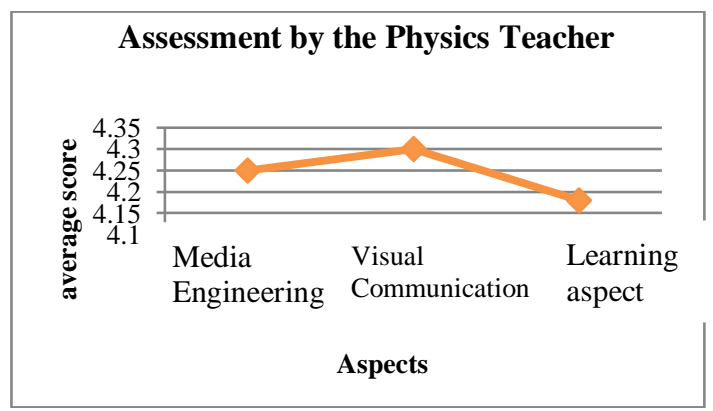

Figure 4. Physics teacher's response toward the developed product
The results of the physics teacher's assessment, the average score of 4.25 was gained that falls into the very high category on media engineering aspects, the average score of 4.30 was gained that falls into very high category for the visual communication aspect, and the average score of 4.18 was gained that falls into very high category for aspects of learning. So, as a whole, the physics monopoly game developed got the response within the very high category for all aspects with the average score of 4.25 .

\section{b. Students' Response}

Students' responses toward the developed were taken through 3 aspects of assessment, namely media engineering aspect, visual communication aspect, and learning aspect through a small grouptesting stage and field-testing stage. Small group testings were conducted to 10 students and the field-testing to 30 students of the State Junior High School Gadingrejo. These results are generally presented in graphical form in Figure 5.

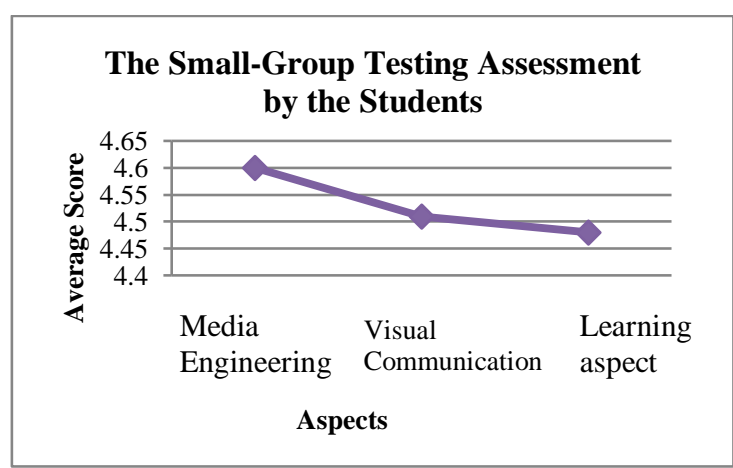

Figure 5. Students' response toward the developed learning media

The results of the students' response through small- group testing obtained a mean score of 4.60 which is in the very high category for media engineering aspects, the average score of 4.51 which fall into the very high category for visual communication aspects was gained, and the average score of 4.48 which fall into very high category for the learning aspect 
was also gained. So, developed physics monopoly game as a whole got response of very high category for all aspects with the average score of 4.53 .

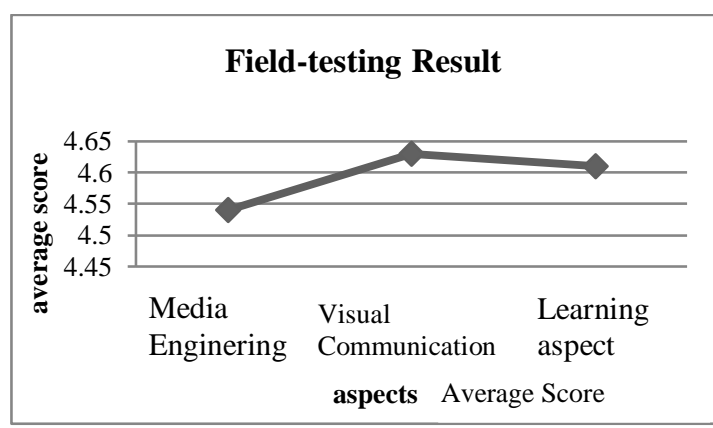

Figure 6. Students' response toward the developed product

The result of the assessment of the field-testing, the average score of 4.54 was obtained that belong to the very high criteria for media engineering aspects, the average score of 4.63 was obtained that belong to the very high category for the visual communication aspect, and the average score of 4.61 that belong to the very high category for the learning aspect. So, the developed Physics monopoly game as a whole got the response with the very high criteria for all aspects with the average score of 4.59 .

The advantages of physics monopoly game on the subject of light and optical devices are:

a. Overall, the learning media of physics monopoly game felt into the Very Good category for all aspects, namely media engineering aspect, visual communication aspect, and learning aspect, so it can be used as one of learning media both inside and outside of class.

b. The aspects that may cause negative effects to the students were charged with the aspects of education as a medium of learning. For example, the money used in monopoly game is replaced with flashcards to minimize the emergence of the nature of materialism; the "Jail" section of the original monopoly was replaced with the instruction to open a worksheet to avoid negative impression for students.

c. This learning media is equipped with question cards containing various questions that get the assessment with the very good criteria for the adequacy of the question numbers, the completeness of the scope of the problem, and the variation of the problem that can be used as student training materials to answer questions related to the material of light and optical devices.

This learning media was supplemented by the results of the students' rating card in the field-testing, the average score of 4.54 was obtained which belong to the very good category for media engineering aspects, and the average score of 4.63 was obtained which belong to the very high category for aspects of learning. So, the developed physics monopoly game as a whole got the response with the very good category for all aspects with the average score of 4.59.

The advantages of learning of physics monopoly game on the subject of light and optical devices are:

a. Overall, the learning media of monopoly physics game got the assessment with the very high category for all aspects, namely media engineering aspect, visual communication aspect, and learning aspect, so it can be used as one of learning media both inside and outside of the classroom.

b. The aspects that may cause negative effects to the students were charged with the aspects of education as a medium of learning. For example, the money used in monopoly game is replaced with flashcards to minimize the emergence of the nature of materialism; the "Jail" section of the original monopoly was replaced with the instruction to open a worksheet to avoid negative impression for students. 
c. This learning media is equipped with question cards containing various questions that get the very good assessment category for the adequacy of the question numbers, the completeness of the scope of the problem, and the variation of the problem that can be used as student training materials to answer questions related to the material of light and optical devices.

d. The collection of information related to learning materials that got a very good assessment category for the appropriateness of the learning materials with the basic competence, learning indicators, learning objectives, and actuality of the material presented, so it can be used as learning materials for students and increase the knowledge of students

e. The physics monopoly game is designed in a different form than the general monopoly game. In this media, the rules and procedures of the game of physics monopoly are described in a game manual equipped with drawings and supporting manuals which got a very high assessment category for indicators of clarity of instructions, so it can facilitate the students in understanding the course of the game.

f. This media comes with an answer key for the question cards that got a very good assessment category for the accuracy aspect, so it can provide immediate feedback to students. In addition, the key answer can be used as a guide to correct students' answers to the questions contained in the question card.

g. The use of physics monopoly game as a learning media can increase participation of the students because in the course of the game, all students are directly involved either as a player or officer with their respective duties. In addition, the use of learning media can also increase the motivation of students.

h. The use of physics monopoly game as a learning media can make learning more enjoyable, without neglecting the actual learning objectives. Because in this media one of the rules requires the students to identify the questions that cannot be answered during the game by confirming the teacher's answer. At the end of the game, students are asked to confirm the information gathered by the teacher during the game, so that it can be used as correction material by the teacher.

The weaknesses of the developed learning media are:

a. Monopoly is a game that has the characteristics of competition and power struggles, to avoid the negative things arises, the teacher as a facilitator in learning and director of the game should emphasize to the students that the media used is for learning purposes.

b. Monopoly game is a group game that is difficult to control as not to be separated from the actual learning objectives. Therefore, teachers as facilitators in learning and directors in the use of media must affirm that the use of learning media of this game is not only for playing games, but at the end of the game, the students are asked to confirm any questions that cannot be answered, and what information the students get during the game.

\section{CONCLUSION AND SUGGESTION Conclusion}

1. The specific needs of the developed learning media of physics monopoly game on the subject of light and optical devices such as the need for filters by researchers to eliminate, replace or modify various components in the game that allows the negative impression on students into elements of education, so the physics monopoly game can be used 
as a medium of learning. In addition, it takes materials such as 210 gram of art paper and Linen to print the physics monopoly game designs, since the quality of those materials is suitable for developing this media; 2 . The feasibility of learning media of physics monopoly game on the subject of light and optical devices in terms of media engineering, visual communication aspect, and learning aspect based on the result of media and material expert validation in the whole development stages is in the very high category, it means that the media deserves to be used as a media in learning; 3. Teachers and students' responses toward the learning media of the physics monopoly game on the subject of light and optical devices in terms of media engineering, visual communications aspects, and overall learning aspects are in the very high category.

\section{Suggestion}

The teachers could utilize learning media such as physics monopoly game in teaching and learning activity especially in the light and optical devices; For further researchers, it is better to broaden the target of the product into a wider range.

\section{REFERENCES}

Diani, R. (2015). Pengembangan Perangkat Pembelaran Fisika Berbasis Pendidikan Karakter Dengan Model Problem Basen Instruction. Jurnal Ilmiah Pendidikan Fisika Al-Biruni, 4(2), 241-253. Retrieved from https://doi.org/10.24042/jpifalbiruni. v4i2.96

Hatika, R. G. (2016). Peningkatan Hasil Belajar Fisika dengan Menerapkan Model Pembelajaran Advance Organizer Berbantu Animasi Komputer. Jurnal Pendidikan Fisika
Indonesia, $\quad$ 12(2), 113-117. Retrieved from https://doi.org/10.15294/jpfi.v12i2.5 210

Komikesari, H. (2016). Peningkatan Keterampilan Proses Sains dan Hasil Belajar Fisika Siswa pada Model Pembelajaran Kooperatif Tipe Student Team Achievement Division. Jurnal Keguruan Dan Ilmu Tarbiyah, 1(1), 15-22.

Magdin, M., \& Turcanini, M. (2016). Modeling Behavior of Students in Elearning Courses on the Basis of Use Interactive Animations. Turkish Online Journal of Educational Technology, 15(1), 62-68.

Manrulu, R. H., \& Sari, D. N. (2015). Efektivitas Kegiatan Lesson Study dalam Merancang Pembelajaran pada Mata Kuliah Gelombang dan Optik. Jurnal Ilmiah Pendidikan Fisika Al-Biruni, 4(2), 229-239. Retrieved from https://doi.org/10.24042/jpifalbiruni. v4i2.95

Peraturan Pemerintah Republik Indonesia. Peraturan Pemerintah Republik Indonesia No.19 Tahun 2005 tentang Standar Nasional Pendidikan Pasal 42,ayat 1 (2005).

Relisa. (2016). Kajian Prasarana Pendidikan Sekolah Dasar sebagai Salah Satu Indikator Pencapaian Standar Nasional Pendidikan. Jurnal Pendidikan Dan Kebudayaan, 1(1), 81-96.

Sadiman, A. S. (2012). Media Pendidikan: Pengertian,

Pengembangan dan

Pemanfaatannya. Depok: Rajawali Pers.

Saregar, A., Latifah, S., \& Sari, M. (2016). Efektivitas Model Pembelajaran CUPs: Dampak Terhadap Kemampuan Berpikir Tingkat Tinggi Peserta Didik Madrasah Aliyah Mathla'ul Anwar Gisting Lampung. Jurnal Ilmiah 
Pendidikan Fisika Al-Biruni, 5(2), 233-243.

https://doi.org/10.24042/jpifalbiruni. v5i2.123

Saregar, A., \& Sunarno, W. (2013). Eksperimen dan Demonstrasi Diskusi menggunakan Multimedia Interaktif ditinjau dari Sikap Ilmiah dan Kemampuan Verbal Siswa. Jurnal Inkuiri, 2(2), 100-113.

Sartikaningrum, R. (2013). Pengembangan Media Pembelajaran Permainan Monopoli Akuntansi untuk Meningkatkan Motivasi Belajar Siswa Kelas X Program Keahlian Akuntansi SMK Negeri 1 Tempel. Universitas Medan. Retrieved from https://doi.org/10.1007/s13398-0140173-7.2
Simbolon, D. H., \& Sahyar. (2015). Pengaruh Model Pembelajaran Inkuiri Terbimbing Berbasis Eksperimen Riil dan Laboratorium Virtual Terhadap Hasil Belajar Fisika Siswa. Jurnal Pendidikan Dan Kebudayaan, 21(3), 299-316.

Wardoyo, T. C. T., \& Ma'arif, F. (2015). Pengembangan Media Pembelajaran Berbasis Video Animasi pada Mata Pelajaran Mekanika Teknik di SMK Negeri 1 Purworejo. Jurnal Pendidikan Teknik Sipil Dan Perencanaan, 1-7.

Yusuf, M. T., \& Amin, M. (2016). Pengaruh Mind Map dan Gaya Belajar terhadap Hasil Belajar Matematika Siswa. Tadris: Jurnal Keguruan Dan Ilmu Tarbiyah, 1(1), 85-92. 